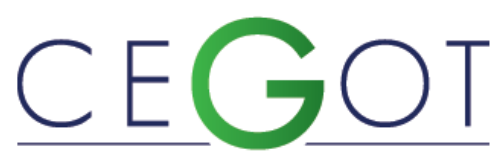

Centro de Estudos de Geografia e Ordenamento do Território
BIRRO, SHEYLA OLIVIA GROFF

Universidade Federal de Jataí (UFJ)

Programa de Pós Graduação em Geografia 75804-020, Jataí-Goiás, Brasil

birrosheyla@hotmail.com

ORCID: https://orcid.org/0000-0003-0910-7317

ROSS, JURANDYR LUCIANO SANCHES

Universidade de São Paulo (USP)

Departamento de Geografia da Faculdade de Filosofia, Letras e Ciências

Humanas da Universidade de São Paulo (USP).

05508-220, São Paulo- São Paulo, Brasil

juraross@usp.br

ORCID: http://orcid.org/0000-0002-7726-2960

CABRAL, JOÃO BATISTA PEREIRA

Universidade Federal de Jataí (UFJ)

Programa de Pós Graduação em Geografia

75804-020, Rua Riachuelo 1530, Setor Samuel Graham, Jataí, Goiás, Brasi

ibcabral2000@yahoo.com.br

ORCID: https://orcid.org/0000-0003-2046-5975

\title{
ANALYSIS OF ENVIRONMENTAL FRAGILITY IN THE AREA OF DIRECT INFLUENCE OF THE ESPORA HYDROELECTRIC POWER PLANT IN CORRENTE RIVER, GOIÁS, BRAZIL
}

ANÁLISE DA FRAGILIDADE AMBIENTAL NA ÁREA DE INFLUÊNCIA DIRETA DA HIDRELÉTRICA ESPORA, NO RIO CORRENTE, EM GOIÁS, BRASIL

Referência: Birro, Sheyla Olivia Groff; Ross, Jurandyr Luciano Sanches; Cabral, João Batista Pereira (2021). ANALYSIS OF ENVIRONMENTAL FRAGILITY IN THE AREA OF DIRECT INFLUENCE OF THE ESPORA HYDROELECTRIC POWER PLANT IN CORRENTE RIVER, GOIÁS, BRAZIL. Revista de Geografia e Ordenamento do Território (GOT), no 22 (Dezembro). Centro de Estudos de Geografia e Ordenamento do Território, p. 140 - 163, dx.doi.org/10.17127/got/2021.22.006

\begin{abstract}
In recent decades, the construction of reservoirs (Small Hydroelectric Centrals and Hydroelectric Power Plants) in hydrographic basins has caused several changes in the landscape, making it necessary to evaluate the synergistic and cumulative effects resulting from the environmental impacts caused by the set of hydroelectric projects. Changes in natural components can result in a loss of system functionality and disruption of its state of balance, which can be assessed through environmental fragility. In this sense, the present work aimed to identify and evaluate the areas with the highest and lowest degree of Potential Fragility and Emerging Fragility, in a delimitation of the influence area of the Espora Hydroelectric Power Plant (HPP) located on the border of the municipalities of Serranópolis and Aporé/GO, Brazil . The methodological procedure adopted is that of environmental fragility through the relationship between soil factors, declivity, geology/geomorphology,
\end{abstract}


precipitation and land use. As a result, the predominance of Laterite, sandy and medium texture soils was detected in lands that went from flat to wavy, occupied by extensive pastures and monoculture. The study area was classified for potential fragility in $3.1 \%$ - very low, $46.8 \%$ - low, $49.5 \%$ - average and 0.6 as high potential fragility based on the relationship of soil, slope and climate factors. However, the emerging fragility showed that the use of land had a significant impact on the rates, mainly in agricultural areas, increasing the fragility, characterized in 19.9 - low, 42.4\% - average, 17.6 - high fragility. It was noted also that very low emergent fragility increased due to the presence of vegetation cover highlighted in the land use map.

Keywords: Hydrographic Basin; Environmental impacts; Hydroelectric Plants; Land Use.

\section{RESUMO}

Nas últimas décadas, a construção de reservatórios (UHEs e PCHs) nas bacias hidrográficas, tem ocasionado diversas alterações na paisagem, sendo necessário avaliar os efeitos sinérgicos e cumulativos resultantes dos impactos ambientais ocasionados pelo conjunto dos aproveitamentos hidrelétricos. As alterações nos componentes naturais podem resultar em uma perda de funcionalidade do sistema e ruptura do seu estado de equilíbrio, que pode ser avaliado por intermédio da fragilidade ambiental. Neste sentido o presente trabalho visou identificar e avaliar as áreas com maior e menor grau de Fragilidade Potencial e Fragilidade Emergente, em uma delimitação da área de influência da Usina Hidrelétrica (UHE) Espora localizada na divisa dos municípios de Serranópolis e Aporé/GO, Brasil. O procedimento metodológico adotado é o da fragilidade ambiental por intermédio da relação entre os fatores solos, declividade, geologia/geomorfologia, precipitação e uso da terra Como resultado, detectou-se a predominância de solos tipo Latossolos, textura arenosa e média, distribuídos em áreas planas a onduladas, ocupadas por extensas áreas de

pastagens e monoculturas. A área de estudo foi classificada como 3,1\% muito baixa, 46,8\% em baixa, 49,5\% em média e 0,6 em alta fragilidade potencial a partir da relação dos fatores solo, declividade e clima. Entretanto, a fragilidade emergente mostrou que o uso da terra incidiu significativamente nos índices, principalmente em áreas de agricultura, elevando a fragilidade, caracterizada em 19,9 baixa, 42,4\% como média, 17,6 em alta fragilidade, notouse também que a fragilidade emergente muito baixa aumentou em razão da presença da cobertura vegetal destacada no mapa de uso da terra.

Palavras-chave: Bacia Hidrográfica; Impactos Ambientais; Hidrelétricas; Uso da Terra.

\section{Introduction}

The concern about environmental impacts or the economic damage resulting from the lack of environmental planning has made the search for studies on environmental fragility increasingly constant, which ends up extending discussions regarding its efficiency and the importance of its various methodologies. 
According to Ross (2006, p. 97), the watershed is chosen as a unit of analysis in fragility studies mainly due to the relationships of the existing and interconnected elements, which make it possible to make analogies and interpret the functioning of a smaller delimitation of space. Fierz (2015, p. 610) mentions that Sotchava, in his theory on geosystems in 1977 , already stated that all elements of space influence or are influenced by other elements, through exchange of energy and matter. Likewise, when a delimitation is made, it is possible to perform a better analysis of these relationships in a given space.

Geomorphological studies in environmental planning, in general, propose the integrated analysis of the environment, in order to seek answers about its elements, in such a way to consider the relief, climate, forms of use, type of vegetation, rainfall, pedology and geology (Ross, 1994, 63-73). With the help of Geographic Information Systems - GISs, these elements are arranged on maps, which, when superimposed and through weighting of variables, may indicate the most susceptible areas to the occupation or installation of enterprises.

For Ross and Fierz (2017, p. 65), GISs over the years have become the main tools for the study and diagnosis of watersheds. This is because GISs help in the integration of information from each variable chosen for analysis and the information contained in maps, especially pedological, geological and land use. With this, it is possible to superimpose thematic maps and data of the physical characteristics of each area of interest, as well as adding historical images of areas relative to use and occupation, making it possible to collect more actual data of the characteristics of each drainage network and highlight areas that may have potential for processes that point to levels of fragility (França et al, 2017, p. 24).

Based on Tricart's Eco-dynamic concept, of 1977, Ross (1994, 63-73) presented a methodological proposal for analyzing the fragility of stable and unstable environments, classifying in hierarchical levels the characteristics found within each variant defined for analysis. Thus, the dynamics of the functioning of a geosystem can only be understood through the integrated analysis of a territory, due to the diversity of both the natural physical characteristics and the characteristics imposed by the occupation of a given territory.

The idea brought by the methodology proposed by Ross $(1994,63-73)$ is that all these components of the geographic stratum should be surveyed and analyzed individually, as they are distinct, but they must be analyzed in an integrated way, "always based on the principle 
that nature has intrinsic functionality between its physical and biotic components" (Ross and Fierz, 2017, p. 66).

The installation of Hydroelectric Power Plants in recent years, according to Gallardo et al (2017, p. 22-47), has generated new dynamics in the landscape, accelerated existing degradation processes or initiated new processes and the loss of the natural landscape, resulting from the installation of large enterprises, as well as the "extinction of rapids and the emergence of lakes, in addition to the resulting decrease in biodiversity, emergence of erosive processes and the generation of pollutants, mainly in flooded areas" (Gallardo, 2017, p, 33).

Currently, the use of water resources depends on diagnostic studies of environmental quality. Each environment, if respected and studied, can determine the type of occupation to be carried out, thus avoiding the evolution of erosive processes and environmental disasters, mainly associated with the change of river channels with the creation of reservoirs in large dams.

For Morais et. al (2010), the factors that influence the water regime and the production of sediments in Brazilian basins depend on the systemic action of natural conditions and human activities. Thus, it is admitted that some basins have higher levels of fragility, due to the pedological and geological characteristics, as well as the interaction with the characteristic rainfall patterns of each region or section.

Among energy generation activities, hydroelectric plants was the fastest growing in Brazil, since the 70s of the 20th century. (Albuquerque et al., 2010; Gallardo et al, 2017). From this, the impacts on hydrographic basins, the main unit for the environmental analysis, became constant and cumulative, if we consider that a single basin receives the installations of one or more Small Hydroelectric Centrals and Hydroelectric Power Plants.

In Brazil, CONAMA Resolution No. 001/86 establishes the definition of environmental impacts, which impacts are classified in the resolution as direct and/or indirect, which is also established by directly and indirectly affected areas of influence. Carvalho et al (2018, p. 641) state that the Area of Direct Influence - ADI encompasses areas in which the impacts generated directly affect the environment and/or society, and may cover the area of the hydrographic basin where it is included, taking into account rural properties and surrounding 
communities. Therefore, based on the choice of the study area where diagnosis is to be carried out, it is possible to establish a cutout for the area of influence of the impact.

In view of the need to assess the different landscape delimitations and mainly discuss the impacts of the reservoirs and the weaknesses that may result from land use in these areas, the area chosen for the present study was the area of direct influence of the Espora Hydroelectric Power Plant, which has about $30 \mathrm{~km}^{2}$ and is installed in the Corrente River, approximately $455 \mathrm{~km}$ southwest of Goiânia, with a distance of $55 \mathrm{~km}$ from the urban area of Serranópolis/GO.

The general objective of the present study was to detect sites with the lowest and highest degree of environmental fragility in the Area of Direct Influence (ADI) of the Espora Hydroelectric Power Plant (HEPP), through the integration of data, aiming to collaborate with the management and planning of the Corrente River basin.

According to the company Espora Energética S.A. (Espora), the project was created in May 2001. The installation of the Espora HPP took place in a rural area, with no need to relocate people or houses. The reservoir area occupies $28,057 \mathrm{~km}^{2}$ and its dam is $45.78 \mathrm{~m}$ high. It has been granted for use for 35 years. As we will see later, the area has a history of occupation by pastures, and this has been gradually replaced in recent years by monocultures of mostly corn, soybeans and sugarcane.

The delimitation comprises the directly affected portion of the reservoir area, in this case, considering the physical impoundment of the HEPP and its influence, comprising an area of $839.3 \mathrm{~km}^{2}$ and a perimeter of $181 \mathrm{~km}$. In view of the large extension of the Corrente River Basin, the area of direct influence was delimited with a natural barrier identified in the first waterfall, upstream of the flooding area, identified in the vicinity of the village of Itumirim/GO, and the springs that comprise the area up to the impoundment. Figure 1 shows the delimitation selected as the area of direct environmental influence, susceptible to changes caused by changes in the form of use and occupation after installation of the HEPP. 


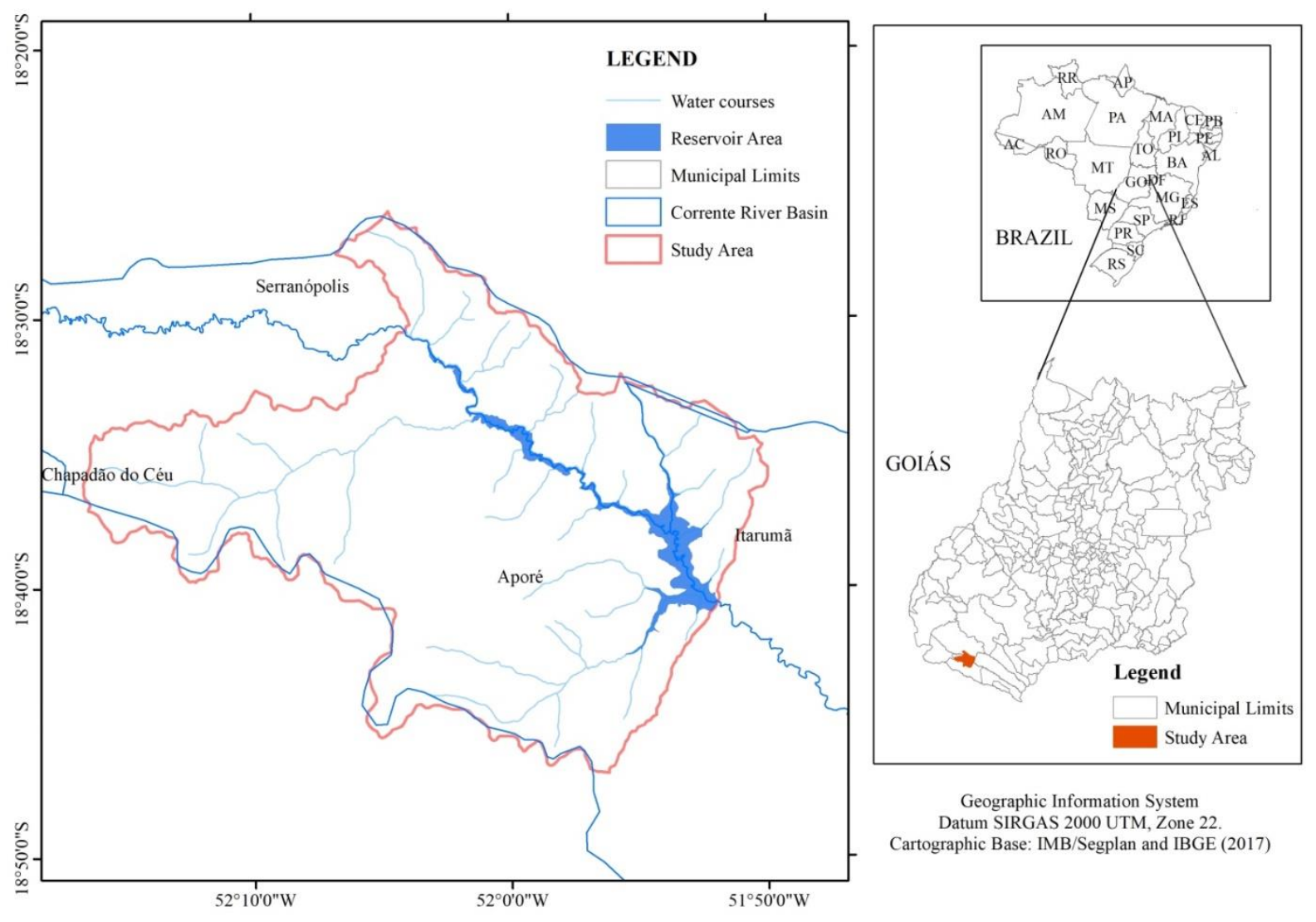

Figure 1 - Location Map of the ADI of Espora HEPP.

Organization: Authors (2019).

\section{Methodological procedures}

This study presented the hypothetical deductive method of analysis, influenced by the methodologies of environmental studies, adopting the landscape as a category of geographic analysis, the river basin as a spatial unit, and, finally, the methodology of environmental fragility, initially proposed by Ross (1994, p. 65) and reviewed by Ross and Fierz (2017, 58-77), as an evaluation model.

Thus, the present study presents the analysis of potential and emerging environmental fragility, in the spatial area of direct influence of the Espora Hydroelectric Power Plant - Espora HEPP, delimited for this study, predominantly covering the municipality of Aporé/GO, in order to understand the characteristics of the different levels of fragility to be found.

The methodological model applied aimed at using the classes of slope, which are also related to the pedological variable, geology/geomorphology, climate and land use and cover. The survey of the variables mentioned, according to Ross (1994, p. 63), is essential for generating 
the synthesis product and geomorphological analysis, the fragility of the site from its genetic characteristics, and the level of intensification of this fragility due to anthropic influence.

Thus, climatic characteristics were surveyed and geomorphology/geology map, to understand the dynamics caused by slope, land use map and pedological map were generated, considering that only after obtaining these maps on can generate Potential Fragility and Emerging Fragility maps. Table 1 shows the classification of the variables found in the area and the score applied according to their variations in slope, land use, climate and pedology.

Table 1 - Classification of fragility levels per variable.

\begin{tabular}{lcc}
\hline & VARIABLE & FRAGILITY \\
& Slope & 1 \\
\hline $0-2 \%$ - Flat & & 2 \\
\hline $3-15 \%$ - Gently Undulating & 3 \\
\hline $16-30 \%$ - Undulating & 4 \\
\hline $31-50 \%$ - Strongly Undulating & 1 \\
\hline Natural vegetation & Land use & 1 \\
\hline Flooded Areas & & 3 \\
\hline Pasture & & 4 \\
\hline Agriculture & Climate & 2
\end{tabular}

Uneven Annual Distribution

(Dry periods between 2 and 3 Months in Winter and Rainfall volumes from 1,300 to 1,600 $\mathrm{mm} /$ year).

\begin{tabular}{lc}
\hline & Pedology \\
\hline Medium-textured Latossolos (Oxisols) & 2 \\
\hline Sandy-textured Latossolos (Oxisols) & 3 \\
\hline Neossolos (Entisols) & 4
\end{tabular}

Organization: Authors (2019)

The present study was conducted using geoprocessing application procedures, constructing the maps from Shuttle Radar Topography Mission - SRTM images, obtained through the site 
of the United States Geological Survey (USGS, 2015), with spatial resolution of $30 \mathrm{~m}$, and the cartographic bases obtained through the RADAMBRASIL Project (1981) and from the database of the Goiás State Geoinformation System - SIEG. The processing of these databases, both for the delimitation of the basin area and for the physical aspects, was carried out with ArcMap $10.1^{\circledast}$ geoprocessing software (ESRI, 2015), licensed for use in the Geoinformation Laboratory of UFG/Regional Unit of Jataí. Thus, maps of geology, pedology, geomorphology, hypsometry, slope and land use and cover were generated.

For the characterization and evaluation of pedology, geology and geomorphology of the area, surveys were carried out in laboratory, together with analyses of existing maps, in the database RADAMBRASIL Folha SD 22 - Goiás (1981), at a scale of 1,000,000. The Geological/Geomorphological map, elaborated from this database, was used as a support for the analysis of the identification of influences by morpho-structure and morpho-sculpture, aiming at greater level of detailing in the field, for a scale of 1:100,000, with particle-size analysis of soils, characteristics of relief and vegetation, also relating to the existing data of the parent material, relief, climatic and hydraulic conditions, general characteristics, which are fundamental in the characterization in the research area.

The pedological classification was performed based on the classification of the Brazilian Soil Classification System - SiBCS, by Santos et al. (2018, 356p), which establishes 6 categorical levels, where the first four levels are called orders, suborders, major groups and subgroups, while the others have atypical characteristics and remain under discussion for classification, along with the opening of pedological profiles in the field, as well as collection and granulometric analysis.

To construct the Digital Elevation Model (DEM) and generate hypsometry and slope maps, the river basin was delimited by the topographic factor, applying the procedure already described by Souza (2012, 12-22), with SRTM images, using the following processing commands in ArcGIS $10.1^{\circledR}$ software; Spatial analyst Tools - Hydrology: - Fill: fill the surface of the image removing small imperfections; - Flow Direction: evaluation of flow direction; - Flow Accumulation: accumulated flow; - Watershed: delimitation of the basin; - Raster to Features: Conversion of the basin, from image to polygon. 
For the survey of climatic data, due to the low distribution of weather stations along the basin and their proximity, bibliographic references about the climate of the region were used, as well as data from bibliographic and scientific materials, based on rainfall levels of the year 2017, collected by the Automatic Surface Observation Meteorological Station of Jataí, for the mode of exhibition of regional characteristics.

These data were made available on the HidroWeb portal (http://hidroweb.ana.gov.br/) under the responsibility of the National Water Agency - ANA, a national database for hydrological information, part of the National Information System on Water Resources - SNIRH. Thus, for confirmation, the rainfall levels of 2017 in the most comprehensive season to the research area were surveyed for analysis of monthly rainfall data, summing all precipitation occurred in the months of this year, and summing the monthly levels to obtain the annual rainfall values.

The land use and cover map of the Corrente River Basin (CRB) was generated by following the methodology of maximum likelihood classification, using images of the Landsat 8 Satellite (2018) made available by the United States Geological Survey (USGS, 2015), with spatial resolution of 30 meters. The information was classified with respect to vegetation cover, pasture, agriculture, silviculture, exposed soil and water mass and confirmed on a field visit. ArcMap $10.1^{\circledR}$ software (ESRI, 2015) was used to generate an automatic classification, Isoseg, a data clustering algorithm that could be reclassified and adjusted with the creation of polygon shapes of each type of use to improve the final results.

To generate potential fragility, the maps of climatic, clinographic and pedological characteristics received new indicators added to the table of attributes, where the field "Fragility" was created so that each item described had a classification, in this case from one to five, according to methodological description of the fragility levels calculated by simple average. This base, generated in polygon, was transformed to Raster through the ArcToolbox tool along with the Conversion Tools>To Raster>Polygon to Raster function, and only then could they be calculated.

The calculation entered in the software program, together with the Spatial Analyst Tools >Map Algebra> Raster Calculator function present in the ArcToolbox tool, used for generating indicators for the Potential Fragility Index - PFI, was expressed by the following formula: 
$\mathrm{PFI}=(1)$ CLIM_VALUE + (2) SOIL_VALUE + (3) SLP_VALUE/3

Where CLIM_VALUE refers to climate, SOIL_VALUE refers to soil and SLP_VALUE refers to slope.

The result of the generation of this map is the basis of the next product, the emerging fragility, which uses the PFI and the base map concerning the delimitation of the areas of land use and occupation, expressed by the formula:

PFI + USE_OCCUP $=\mathrm{EFI}$

Where PFI is the Potential Fragility Index, USE_OCCUP is the base of use and occupation, already changed in its table of attributes, with addition of the levels of fragility by type of occupation, according to the methodology described. EFI is the result of the final product, the Map of Emerging Fragility Index of the area, where the areas of emerging instability were identified according to the types of anthropic interventions and their impacts.

These intermediate cartographic products, along with the result of the mapping of structural features, provided the data necessary to perform the analyses and make considerations.

\section{Results and discussion}

\subsection{Climate Characterization}

According to the studies conducted by Mariano (2005, 251p.) and Lima and Mariano (2014), rainfall and air temperature vary seasonally in the region throughout the year, and this is considered a predominant climatic characteristic in the Brazilian Cerrado. The annual total rainfall levels in 2017 were surveyed and indicated predominance of rainfall distributed between October and May, as well as scarcity of rainfall in the months from June to September. According to the characteristics established in the proposed methodology in application, the climate had classification 3 regarding the level of existing potential fragility, where there is a situation of rainfall with unequal annual distribution, with dry periods between 2 and 3 months in winter (From July to September) and in summer with higher intensities from December to March, with volumes from 1,300 to 1,600 mm/year. 


\subsection{Geology and geomorphology}

The characteristics of Geomorphology and Geology were used as a basis for the analysis of the dynamics of the present relief. The geomorphological map showed that the area is characterized by some portions of plateaus upstream of the reservoir, characteristic in the upper course of CRB. The delimited area is located in a transition from upper to lower course, transporting deposits and detrital sedimentary covers (Figure 2) originating from the weathering processes of the rocks, occurring from the top of the basin, which explains the denomination for the intermediate coalescent surface, present throughout the middle course of the CRB.

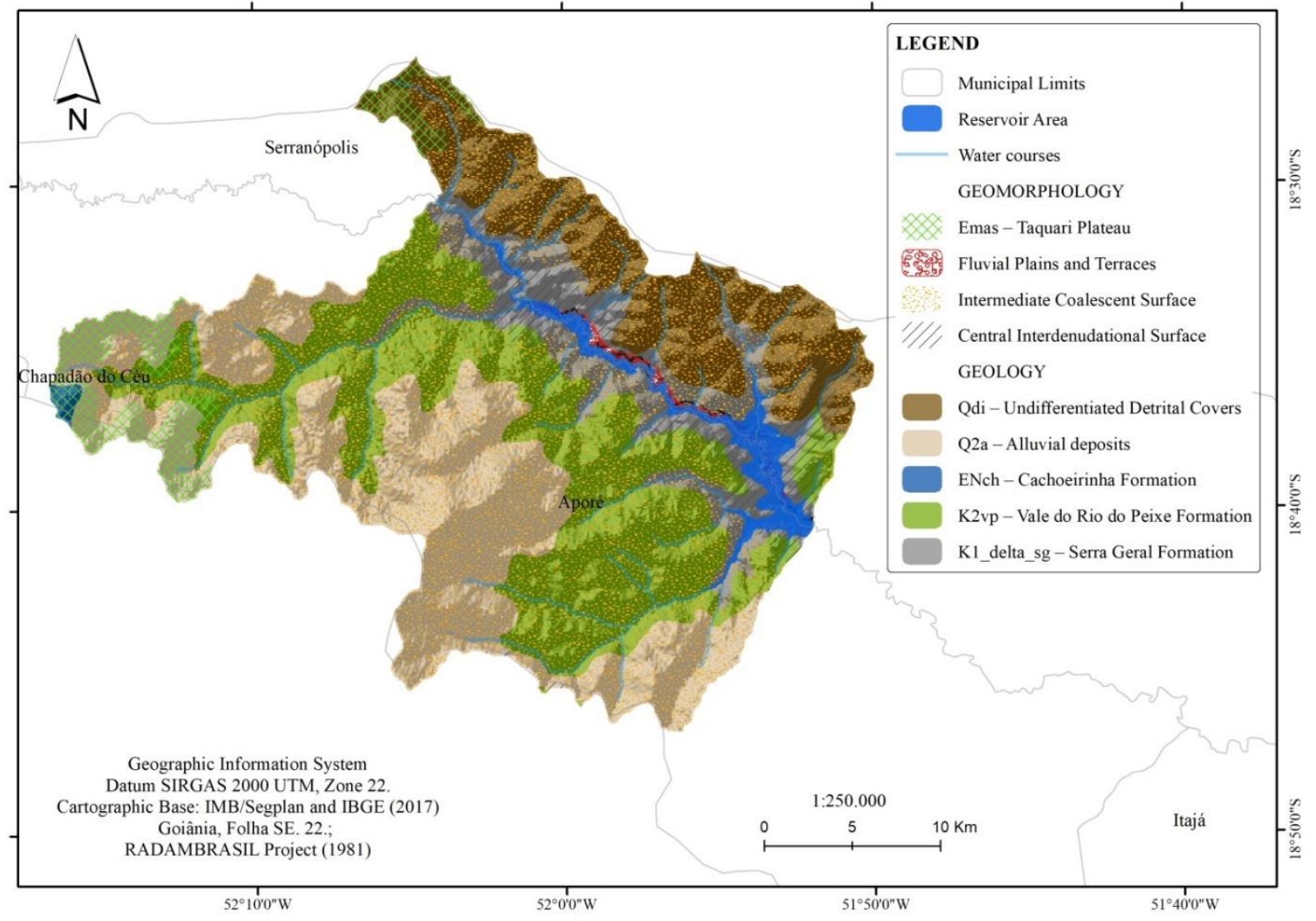

Figure 2 - Integrated map of Geology and Geomorphology of the area.

Organization: Authors (2019).

Santos (2013, p. 63) argues that the interdenudational areas are characteristic of sites that receive material that has been weathered and eroded, coming from steeper areas. Note that this area becomes wider as it reaches the lower course, where there is the presence of the more pronounced reliefs of the Marília Formation. 
Regarding its geology, it is possible to note the presence of the Vale do Rio do Peixe Formation, which according to Fernandes $(2004$, p. 57$)$ has coarse- to fine-grained sandstone and crossed structures. Thus, the presence of this formation was identified along the water courses of the tributaries that flow into the Corrente River, always overlapping with the basalts of the Serra Geral Formation.

According to the description of Souza and Candeiro (2012, p. 9), the Vale do Rio do Peixe Formation is formed by sandstones interspersed with siltstones or sandy mudstones, which can be very fine to fine, pinkish light brown to orange, and uniformly sorted. This could be associated with the sandstones found in the area under study, with orange color and visibly crossed stratigraphy, shown in Figure $3(A)$, identified on the banks of the Corrente River, enabling the identification of the Vale do Rio do Peixe Formation.

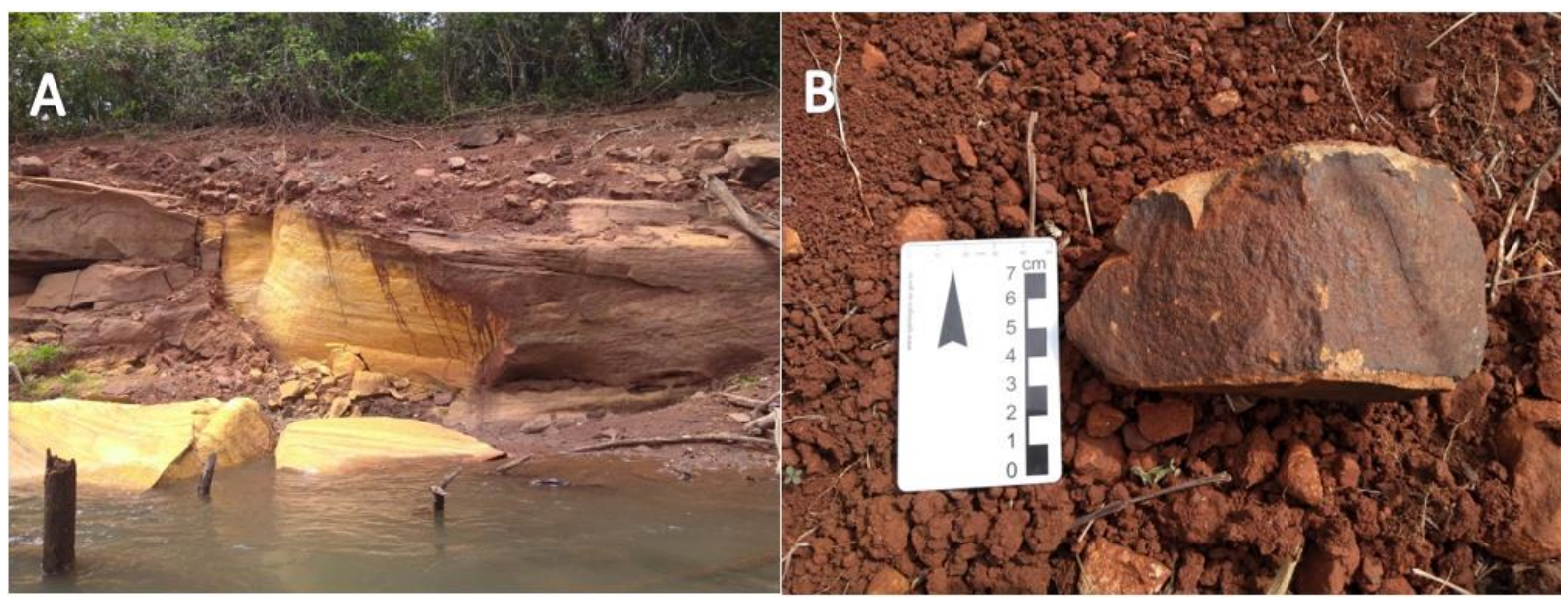

Figure 3 - (A) Sandstone of the Vale do Rio do Peixe formation and (B) Basaltic Rock of the Serra Geral Formation.

Source: Authors' private collection, January 2018.

According to Hartmann (2014, p. 175), the Serra Geral Formation was formed by numerous lava spills, which enabled the formation of several types of volcanic rocks, with different characteristics; "the dominant rocks are basalt, basaltic andesite and andesite, few rhyodacites and rhyolites". The Serra Geral Formation contemplated the entire area of the river valley along this part of the basin and characterizes the areas of waterfalls and rapids identified upstream of this delimitation, as well as some tributaries.

In the area under study, basaltic igneous rocks were also identified, outcropping near the village of Itumirim and characterizing the incidence of steps and rapids along the river. Figure 
3(B) shows an example of a basaltic rock fragment in the study area. The geological characteristics found in the area not only enabled the relationship with local geomorphology, but also the relationship with the textures of the soil types analyzed. This is because the weathering of sandstone in tropical environments can accelerate the process of material breakage, resulting in sandy soils with low compaction capacity, especially in areas of low organic matter concentration (Freitas, 2016, p. 31).

According to Hartmann (2014, p. 175), the Serra Geral Formation was formed by numerous lava spills, which enabled the formation of several types of volcanic rocks, with different characteristics; "the dominant rocks are basalt, basaltic andesite and andesite, few rhyodacites and rhyolites". The Serra Geral Formation contemplated the entire area of the river valley along this part of the basin and characterizes the areas of waterfalls and rapids identified upstream of this delimitation, as well as some tributaries.

In the area under study, basaltic igneous rocks were also identified, outcropping near the village of Itumirim and characterizing the incidence of steps and rapids along the river. Figure 4 shows an example of a basaltic rock fragment in the study area.

The geological characteristics found in the area not only enabled the relationship with local geomorphology, but also the relationship with the textures of the soil types analyzed. This is because the weathering of sandstone in tropical environments can accelerate the process of material breakage, resulting in sandy soils with low compaction capacity, especially in areas of low organic matter concentration (FREITAS, 2016, p. 31).

\subsection{Slope}

Slope was used in this proposal, as the type of mapping does not allow the use of relief dissection for analysis, because the proposal of fragility in the methodology used requires a larger scale, between 1:10,000 and 1:50,000. This study presents scale varieties from 1,50,000 to $1,000,000,000$, because of the already existing database used, and only soil and land use mapping was verified in the field by ground truth.

Thus, the slope map made it possible to use the contour lines existing in the charts of both IBGE and SRTM, of $90 \mathrm{~m}$ and $30 \mathrm{~m}$, to generate the slope; the levels of dissection could not be generated with the cartographic scale used. These adaptations are used for the Midwest 
region of Brazil, given the absence of detailed mapping, as it is in an area of agriculture and livestock farming, which justifies the use of the methodology of Embrapa.

According to Braga et al. (2017, p. 106), "slope is one of the main variables in the mapping of environmental fragility, because the water erosion processes, associated with other factors, can be accelerated according to the degree of slope of the terrain". Thus, in order to know the influence of slope on the incidence of local fragility, the slope of the area was generated considering the classification established by Ross and Fierz (2017, p. 58-77).

The local slope map (Figure 4) showed a flat relief in areas of tops and, in some cases, in river valleys, and the gently undulating to undulating relief towards the riverbed. A small stretch of deepening of the river can be seen upstream of the delimited area, with a greater slope, resulting from the presence of basaltic rocks of the Serra Geral Formation identified earlier, forming "steps" of rocks and an area of rapids.

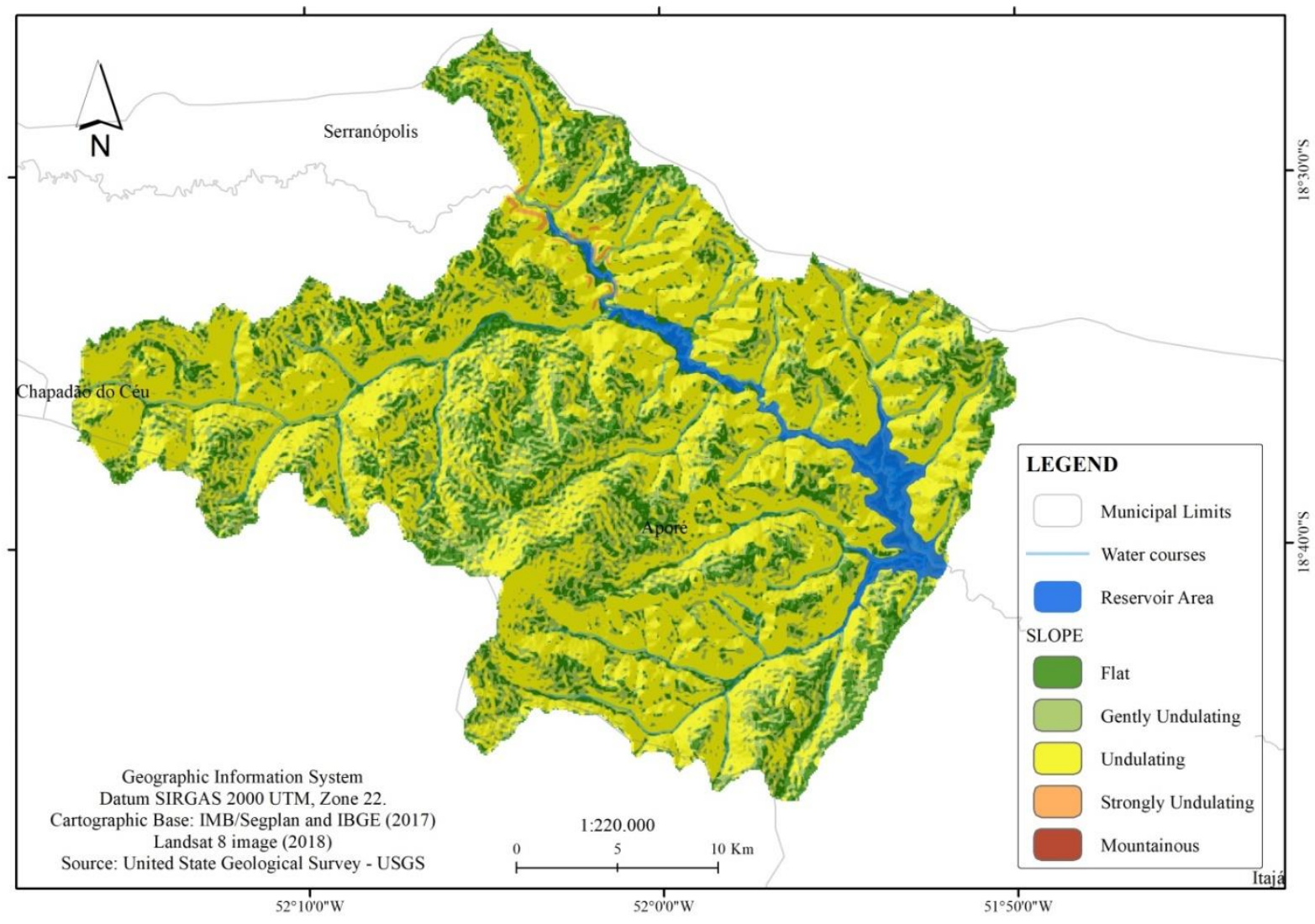

Figure 4 - Characteristics of the slope of the study area.

Organization: Authors (2019) 
Cuiabano et al. (2017, p. 142) state that the slope present in the field, evaluated together with the type and texture of the soils, and the analysis of land use in the study area can help in the prediction of erosive processes, enabling decision-making that contributes to better use of space. Regarding the extents in the area, the slope was mostly classified as undulating (61.5\%) to flat in top areas (28.7\%), according to table 2 , and may not have a great influence on erosive processes, until it is analyzed together with the other products generated.

Table 2 - Result of the percentage of slope classes of the area.

\begin{tabular}{ccc}
\hline SLOPE & $\begin{array}{c}\text { RELIEF } \\
\text { (ROSS AND FIERZ, 2017) }\end{array}$ & $\begin{array}{c}\text { AREA } \\
\text { (\%) }\end{array}$ \\
\hline $\mathbf{0 - 2 \%}$ & Flat & $\mathbf{2 8 . 7}$ \\
\hline $\mathbf{3 - 1 5 \%}$ & Gently undulating & 9.2 \\
\hline $\mathbf{1 6 - 3 0 \%}$ & Undulating & 61.5 \\
\hline $\mathbf{3 1 - 5 0 \%}$ & Strongly Undulating & 0.6 \\
\hline
\end{tabular}

Organization: Authors (2019)

Undulating reliefs require more conservation practices such as terracing for agricultural crops than flat reliefs, where surface runoff is very slow and water erosion is not significant. Although gently undulating areas are very similar, surface runoff is slow, but may indicate greater fragility in sandy soils with long slope (Klein, C.; Klein, 2015, p. 87). It can be noted that each class of slope has characteristics that can affect the final levels of fragility, as they influence the flow of surface waters and have different forms of use and occupation.

\subsection{Pedology}

From the generation of the pedological map, it was possible to notice that much of the basin is located in areas covered by Latossolos (Oxisols), which, according to Santos et al. (2018, p. 84), have both clayey texture and medium to sandy texture. Still, this area has a predominance of sandy soils and some Neossolos Litólicos (Entisols) were identified, which, according to the methodology, can classify the area into a higher level of fragility in relation to the types of soils indicated.

According to Cuiabano et al. (2017, p. 143), density, porosity and the capacity of water retention and infiltration in the soil is what determines its vulnerability to erosive processes. 
Likewise, the intensive and inadequate use of soil can alter density and porosity, influencing physical attributes.

Neossolos Litólicos were identified upstream of the delimited area in the municipality of Serranópolis and Aporé. Soil profiles were opened to confirm the presence, and the following were identified in the basin: Neossolos Litólicos, Latossolos Distroférricos, Latossolos Vermelhos and Latossolos Vermelho-Amarelos (Figure 5). It can be notedthat Latossolos prevail along the basin, showing variation, which can be identified visually by the color, touch and profiles opened. Hydromorphic soils, or Gleissolos (Entisols), present in the lowest areas and wetlands, were also mapped.

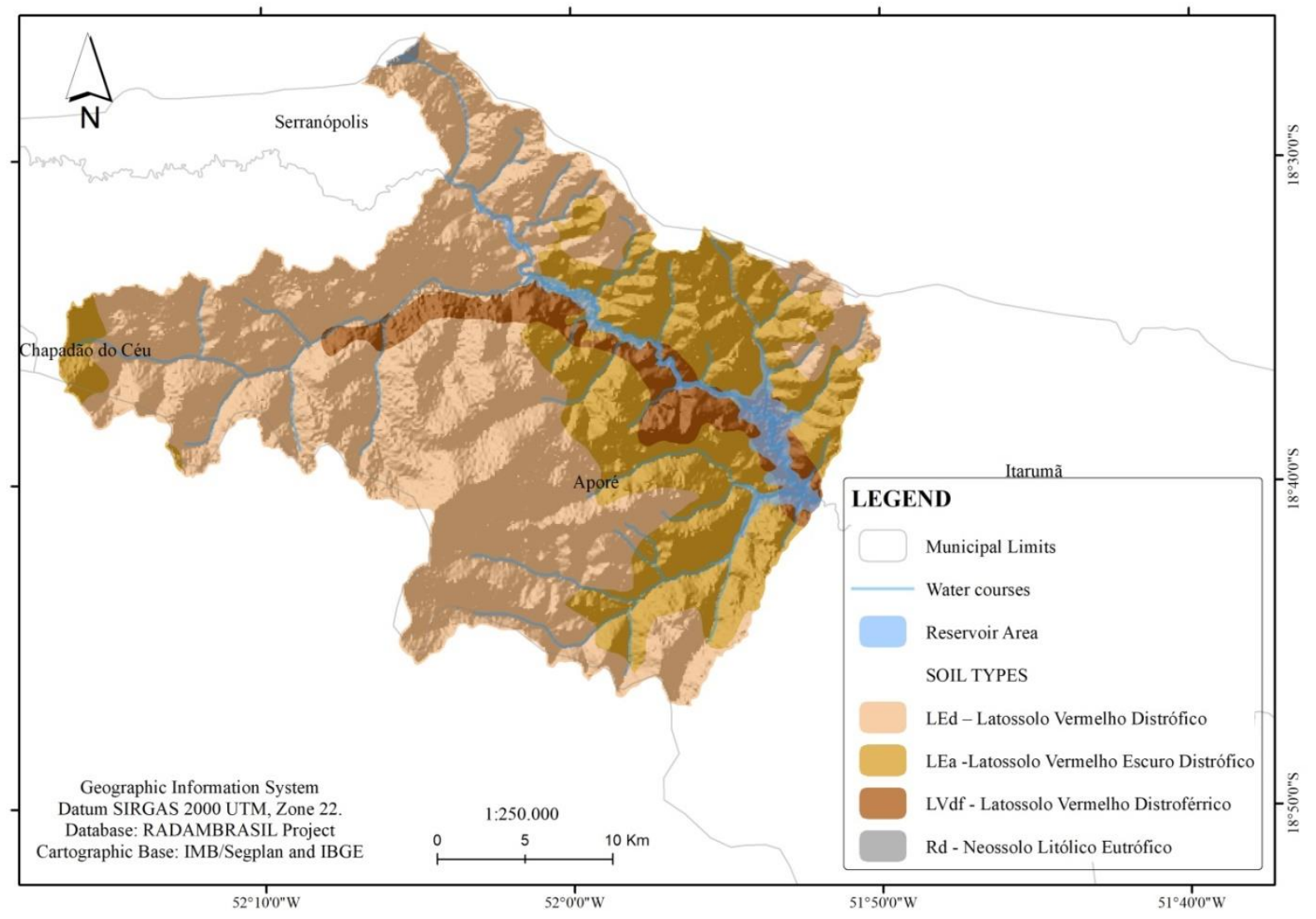

Figure 5 - Soils identified in the field Organization: Authors (2020).

Latossolos can be identified throughout the area and Neossolos Litólicos are easily identified in the field, because they present themselves as decomposing rocks on the surface, described by Santos et al. (2018, p. 96), still to be altered, in this case being present in a flatter area 
upstream of the reservoir area, before the areas of waterfall and the river deepening stretch, identified in middle course.

\subsection{Land use}

The survey of land uses combined with knowledge of soil characteristics is essential for the proper planning of the territory. Cuiabano et al. (2017, p.551) state that "intensive and inadequate land use and management systems can influence physical attributes of soils, predisposing them to degradation, causing damage to their sustainability". The land use map reveals the predominance of pasture and agriculture areas, as shown in the table 3.

Table 2 - Result of the percentage of slope classes of the area.

\begin{tabular}{ccc}
\hline CLASSES OF USE & AREA IN THE BASIN (KM $\left.{ }^{\mathbf{2}}\right)$ & AREA IN THE BASIN (\%) \\
\hline Pasture & 356.1 & 42.5 \\
\hline Agriculture & 319.4 & 38.1 \\
\hline Vegetation & 130.9 & 15.6 \\
\hline Water mass & 27.7 & 3.3 \\
\hline Silviculture & 4.9 & 0.59 \\
\hline
\end{tabular}

Pasture and agriculture (represented by soybean, sugarcane and maize cultivation) and also uses for silviculture predominate among the uses identified in the area of direct influence of Espora HEPP.

We highlight here the impacts of livestock farming, which in addition to the deforestation process, requires areas for animals to drink water, which can also aggravate the siltation of small watercourses that are present in the basin and nourish the main course. In addition, large tracts of sugarcane, soybean and maize crops contribute to the increase in deforestation, increasing soil fragility.

Just as there is a predominance of the use for pastures in the CRB, this delimitation (Figure 6) also identified the same, despite the expansion of agriculture in this region. It can be affirmed that non-conservation land use causes numerous impacts to the environment, involving 
reduction of biodiversity, soil degradation, siltation of water courses, among others (DiasFilho, 2014, p.19), so this type of use can show, in the final product, an increase in the degree of emerging fragility, especially in agricultural areas, when combined with undulating slopes.

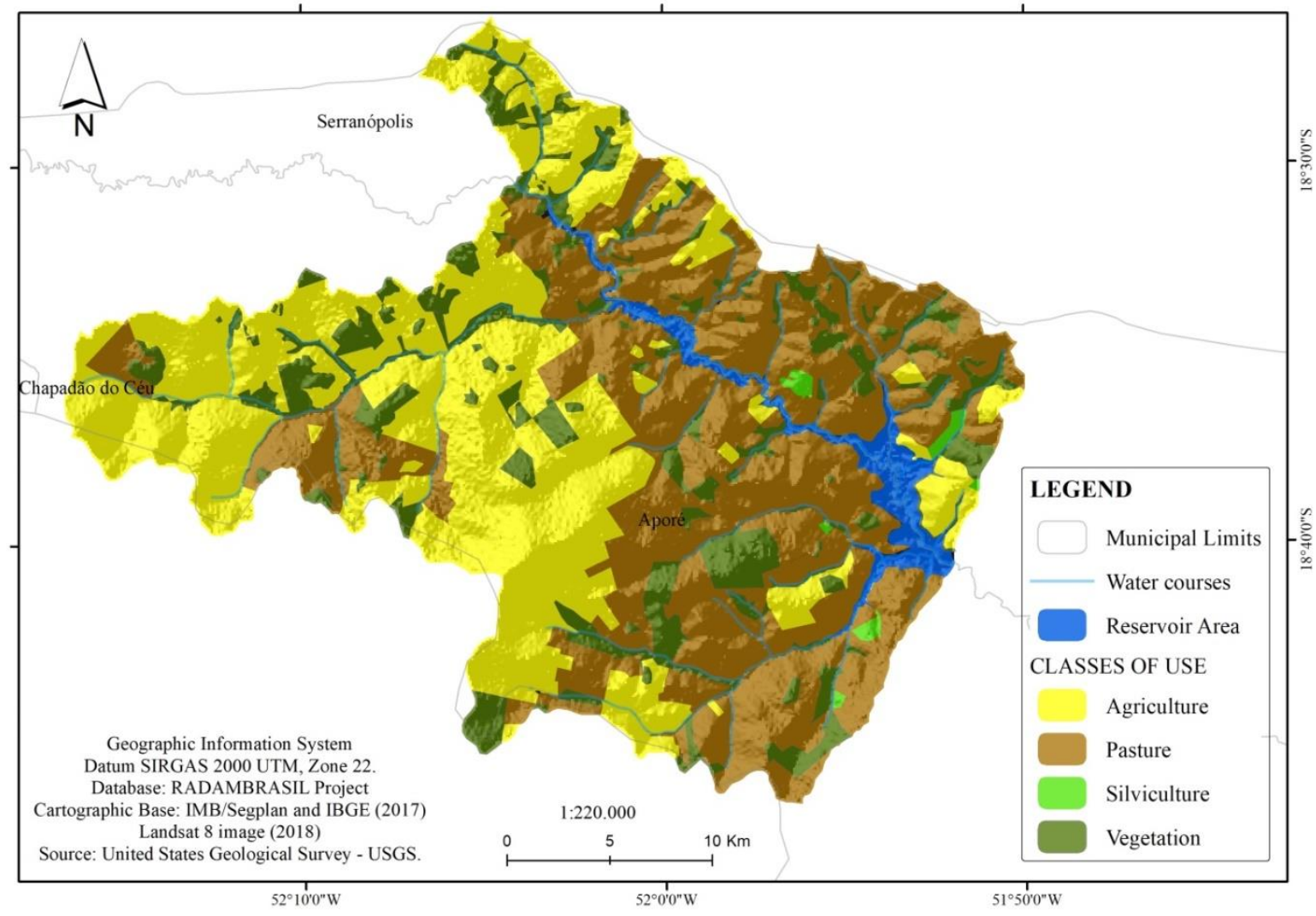

Figure 6 - Land use mapping. Organization: Authors (2019)

The areas covered by temporary crops tend to lose more nutrients, especially in sandy soils, as these are leached and can also contribute to the contamination of springs (Donagemma et al., 2016, p. 1009). The occupation of areas that have very sandy to loamy soils due to agricultural activities, for example, can facilitate the infiltration of insecticides, besides requiring more irrigation, given the difficulty in retaining water, or the opposite can occur, compacted soils can facilitate surface runoff and hinder water retention (Albuquerque Filho et al, p. 355-367, 2010).

The limited areas of native vegetation were identified as areas of mandatory preservation, both in gallery forests and riparian forests, the Permanent Protection Areas and Legal Reserve 
areas. In addition, the absence of these characteristics can cause great influence on the degrees of emerging fragility to be found in the final product of this study.

\subsection{Environmental Fragility}

Based on the results found, the empirical analysis of environmental fragility in the study area was performed using collected and analyzed data of climate, slope, soil and land use. The values of the variables of these results were established according to the methodology of environmental fragility proposed by Ross (1994, p. 63-73) and reformulated by Ross and Fierz (2017, p. 58-77).

The characteristics identified do not establish high levels of potential fragility, which is the result of the climate + slope + pedology correlation, since climate was characterized as of medium fragility throughout the area, and the slope, from flat to wavy, together with the predominance of sandy soils, also helped in these characteristics. Therefore, the map showed a results of $46.8 \%$ for low and $49.5 \%$ for medium (Figure 7 ), due to these factors.

Massa and Ross $(2012$, p. 76$)$ state that "the little dissected relief is in fact more stable, given that fragility is also conditioned by other factors such as soil, land use and occupation and rainfall characteristics".

Thus, this fragility mapping showed that the low to high potential fragility (Figure 7 ) is the result of soil texture, predominantly sandy throughout the area. As stated by Cuiabano (2017, p. 142), clay and organic matter are the main elements that contribute to soil aggregation, and slope is identified as gently undulating to undulating, justifying medium influence on the erosion percentage, along with the low fragility of the climatic classification of the area.

The map of emerging fragility brought the interpolation of potential fragility data along with the type of land use and occupation in the area under analysis. In this case, with greater weight, the use for agriculture, which occupies $38 \%$ of the area, intensified the increase of fragility (Figure 7) as it mainly had characteristics of temporary crops and under intensive use, adding $17 \%$ in area of high fragility.

On the other hand, the presence of vegetation cover generated an increase in areas with very low fragility, shown in Table 4. Donagemma et al. (2016, p. 1010) state that vegetation maintains balance in soils, mainly sandy ones, as it provides greater water retention capacity and stability through its roots, as well as cover. 

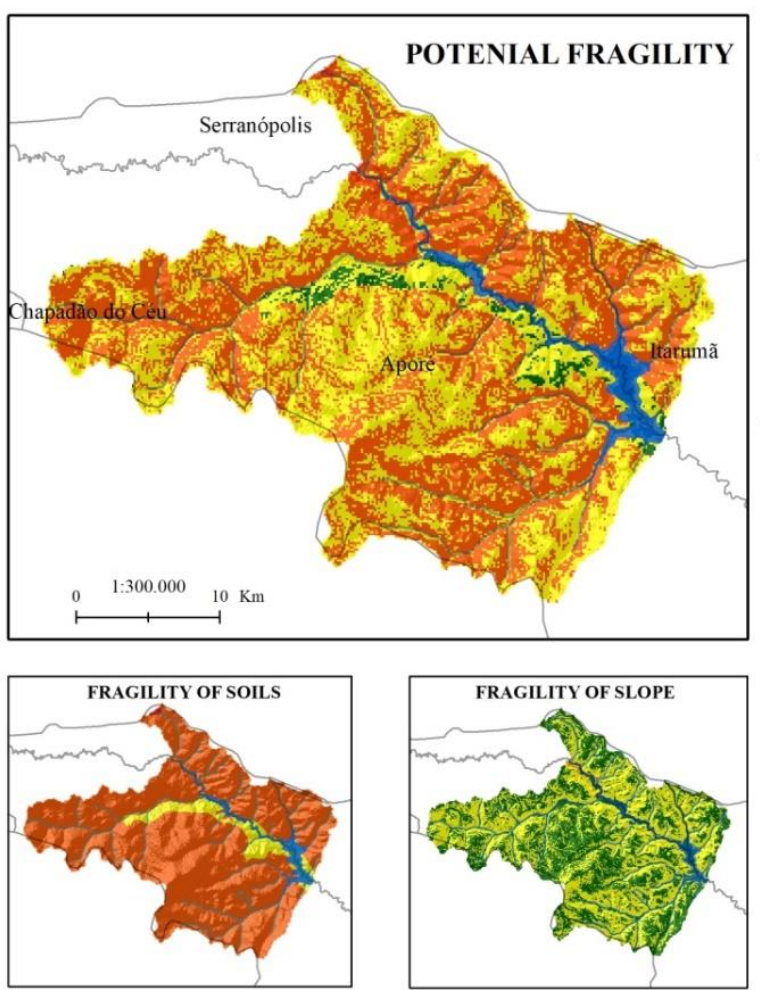

Geographic Information System; Datum SIRGAS 2000 UTM, Zone 22. Topographic Delimitation and Land Use: ALOS/PALSAR image (2007); Municipal Cartographic Base: IMB - SEGPLAN (2017).
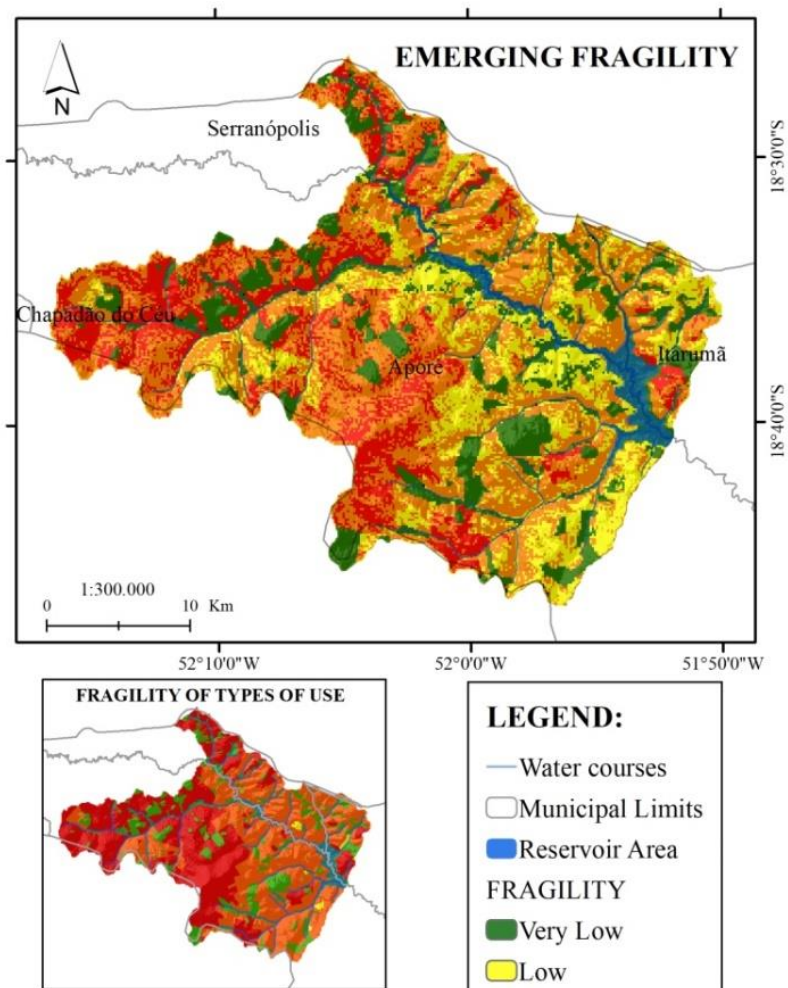

LEGEND:

- Water courses

$\square$ Municipal Limits

Reservoir Area

FRAGILITY

Very Low

$\square$ Low

Medium

High

Figure 7 - Map of Potential and Emerging Fragility

Organization: Authors (2020).

Table 2 - Areas with the levels of Potential Environmental Fragility and Emerging Fragility.

\begin{tabular}{cccc}
\hline POTENTIAL FRAG. & AREA (\%) & EMERGING FRAG. & AREA (\%) \\
\hline Very Low & $3.1 \%$ & Very Low & $20.1 \%$ \\
\hline Low & $46.8 \%$ & Low & $19.9 \%$ \\
\hline Medium & $49.5 \%$ & Medium & $42.4 \%$ \\
\hline High & $0.6 \%$ & High & $17.6 \%$ \\
\hline
\end{tabular}

The areas identified with low and medium emerging fragility mostly covered the use of pastures because, as previously mentioned, this type of use, in general, has lower fragility than agriculture, but is not exempt from soil erosive processes. Despite the large extent and the impacts of degradation on water courses, pastures end up controlling erosive processes, providing organic matter due to grass roots, which also decrease infiltration rate, contributing to some moisture retention in these soils (Dias-Filho et al. 2014, 36p). 
Of the areas classified as of medium level of emerging fragility, $42.4 \%$ are under agriculture and pastures related to soil type and slope, showing that these deserve more attention regarding the type of management. According to Centeno et al. (2017, p. 34), soil texture defines the levels of water infiltration and absorption because, in general, sandy soils have a greater capacity for infiltration of rainwater, which carries nutrients, agricultural correctives and agrochemicals.

It should be remembered that the substitution of vegetation cover by pastures and agriculture areas, as well as the pressure of these uses on rivers and springs, favors the increase of environmental instability, especially with the absence of conservation practices. Thus, it is advisable to have a plan for controlling land use, especially in areas classified as of medium emerging fragility, which can be destined for both livestock activities and agriculture, provided that appropriate soil protection managements and techniques are applied.

\section{Final considerations}

In this study the natural physical factors of the area characterize medium potential fragility, mainly due to the type of soil. In addition, the type of land use leads to increase of emerging fragility, considering that the lower potential fragility of the area is directly related to the low slope and the pedological characteristics found, where the sandy texture of Latossolos prevented classification as very low potential fragility, but also did not result in high level of fragility, due to the slope characteristics of the terrain.

This study allows us to state that the integrated analysis of natural and anthropogenic variables allows us to make a reading of the degree of environmental fragility of the environments, whether for adequate planning or for predicting risks. In areas that support large projects, these environments must have continuous monitoring, considering that the change in space, in its various types of uses, is constant. As seen, the studied area is located in the Cerrado area, a central region of Brazil, characterized by mild slopes. Nevertheless, its fragility was shown to be aggravated by the type of use and occupation implemented in recent years. 
Although the area showed a medium potential environmental fragility caused by erosive processes due to slope, special attention is needed regarding the concentrated flow of rainwater both in pasture areas and in crop areas, particularly along roads and service paths on farms. In this case, it is essential to use contour lines and temporary retention boxes alongside these roads, especially in agricultural areas.

The highlighted area of influence of the Espora HEPP is suitable to receive the installation of enterprises, such as the HEPP installed, but requires the application of legislation regarding the permanence of riparian forests and vegetation, in order to contain the siltation process in the reservoir and in the tributaries present.

The methodology of environmental fragility proposed by Ross $(1994,63-73)$ stands out for adapting to the various types of environments and purposes, enabling analysis at various scales. The identification of stable and unstable areas also enables a reading of the existing limitations and potentialities, essential for the planning of the space, which aims at the creation of proposals that point to reduction of impacts and better use of the environment.

The diagnoses of hydrographic basins and areas of influence of large projects, based on environmental mapping, are considered the technical-scientific supports for the development of strategic planning and government management, especially in aiding environmental zoning. Thus, these and other discussions around the planning of the territory must add specific knowledge that is extremely important for the appropriation of the environment to produce a lesser environmental impact.

The discussion presented is expected to provide debates about the importance of Physical Geography studies in analyses that promote a greater man-nature integration and mainly that provide adaptations and basis for other environmental quality studies and for planning and management of the territory.

\section{Acknowledgments}

The present study was carried out with support from the Coordination for the Improvement of Higher Education Personnel - Brazil (CAPES) - Financing Code 001 and also with support 
from the National Program for Academic Cooperation (PROCAD) of CAPES/Brazil - CAPES Call

071/2013 - Process number 88881.068465/2014-01. We appreciate all the support.

\section{References}

Albuquerque Filho J. L.; Saad, A.R.; Alvarenga M.C. (2010) Considerações acerca dos impactos ambientais decorrentes da implantação de reservatórios hidrelétricos com ênfase nos efeitos ocorrentes em aqüíferos livres e suas consequências. Revista Geociências, São Paulo, UNESP. v. 29, n. 3, p. 355-367. https://repositorio.unesp.br/handle/11449/71960.

Braga. L.; Ferreira, S. R.; Uagoda R. E. (2017). Mapeamento de feições erosivas e análise dos fatores controladores da erosão na Bacia Hidrográfica do Ribeirão Contagem - Distrito Federal. Espaço \& Geografia, v.

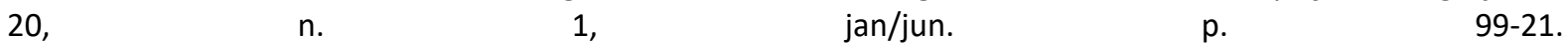
http://www.Isie.unb.br/espacoegeografia/index.php/espacoegeografia/article/view/376/282.

Carvalho, D. N.; Boniolo, M. R; Santos, R. G; Batista, L. V. Malavazzi, A. A; Reis, R. A. G. V. Giordano L. C. (2018). Critérios usados na definição de áreas de influências, impactos e programas ambientais em estudos de impacto ambiental de usinas hidrelétricas brasileiras. São Paulo, UNESP, Geociências, v. 37, n. 3, p. 639-653. https://www.revistageociencias.com.br/geociencias-arquivos/37/volume37_3_files/37-3-artigo-13.pdf

Centeno, L.N; Guevara, M.D.F.; Cecconello, S.T.; Sousa, R.O.D.; Timm, L.C. (2018) Textura do Solo: Conceitos e Aplicações em Solos Arenosos. Revista Brasileira de Engenharia e Sustentabilidade. Pelotas - RS, V. 4, , jul. n. 1, p. 31-37. https://periodicos.ufpel.edu.br/ojs2/index.php/RBES/.

Cuiabano, M. do N; Neves, S. M. A. da S; Nunes M. C. M.; Serafim, M. E.; Neves, R. J. (2017). Vulnerabilidade ambiental à erosão hídrica na sub-bacia do córrego do guanabara/ reserva do Cabaçal-MT, Brazil. Revista Geociências. 36, n 3. P. 543 -556. https://doi.org/10.5016/geociencias.v36i3.11231

Dias-Filho, M.B. (2014). Diagnóstico das pastagens no Brasil. Embrapa Amazônia Oriental. Documentos, BelémPA. 36p.

Donagemma, G.K. Freitas, P.L.; Balieiro, F.C; Fontana A. (2016) Characterization, Agricultural potential, and perspectives for the management of light soils in Brazil. Pesquisa Agropecuária Brasileira. Brasília, V. 51, n. 9, p. 1003-1020. http://dx.doi.org/10.1590/s0100-204x2016000900001.

Fernandes, L.A. (2004) Mapa Litoestratigráfico da Parte Oriental da Bacia Bauru (PR, SP, MG), Escala 1:1.000.000. Boletim Paranaense de Geociências. V. 71, n. 55, Editora UFPR. Curitiba, Paraná, Brazil. p. 53-66. https://revistas.ufpr.br/geociencias/article/view/4283/3439

Fierz, M.M. (2015) A teoria do equilíbrio dinâmico em geomorfologia. Geousp - Espaço e Tempo (Online), São Paulo-SP, Brazil. V. 19, n. 3, p. 605-629. http://www.revistas.usp.br/geousp/article/view/107614

França, L.C.J.; Piuzana, D.; Ross, J.L.S. (2017) Fragilidade ambiental potencial e emergente em núcleo de desertificação no semiárido brasileiro (Gilbués, Piauí). Revista Espacios. Caracas, Venezuela. V. 38, n. 31, p. 2138. http://www.revistaespacios.com/a17v38n31/a17v38n31p21.pdf

Freitas, L.G.B.G. (2016) Caracterização morfológica e mineralógica de perfis de intemperismo de arenitos da Bacia do Paraná no Triângulo Mineiro (MG). [Doctoral dissertation in Federal University of Viçosa]. Theses and Dissertations Archive. Viçosa-MG, Brazil. 80f. https://locus.custom.ufv.br//handle/123456789/10420

Gallardo, A.L.C; Silva, J.C. Gauderetto, G.L.; Sozinho, W.F. (2017) A avaliação de impactos cumulativos no planejamento ambiental de hidrelétricas na bacia do rio Teles Pires (região amazônica). Revista Desenvolvimento e Meio Ambiente, Curitiba-Paraná, Brazil. V. 43, Edição Especial: Avaliação de Impacto Ambiental, p. 22-47, dez. https://revistas.ufpr.br/\%20made/article/view/53818/34467

Hartmann, L.A.F. (2014) A História Natural do Grupo Serra Geral desde o Cretáceo até o Recente. Revista Ciência e Natura, v. 36, ed. especial. p. 173-182. https://periodicos.ufsm.br/cienciaenatura/article/viewFile/13236/pdf 
Klein, C.; Klein, V. A. (2015) Estratégias para Potencializar a retenção e disponibilidade de água no Solo. Revista Eletrônica em Gestão, Educação e Tecnologia Ambiental - ReGet. V. 19, n. 1, jan./abr. Santa Maria-RS, Brazil. p.21-29. https://periodicos.ufsm.br/reget/article/viewFile/14990/pdf

Lima, A. M.; Mariano, Z. F. (2014) Análise microclimática no interior e fora das florestas Estacionais semideciduais na área da bacia da Usina Hidrelétrica de Caçu-GO. Revista do Departamento de Geografia-USP, v. 27, p. 67-87. DOI: https://doi.org/10.11606/rdg.v27i0.444

Lima, A.M.; Mariano, Z.F. (2014) Análise microclimática no interior e fora das florestas Estacionais semideciduais na área da bacia da Usina Hidrelétrica de Caçu-GO. Revista do Departamento de Geografia - USP, V. 27, p. 6787. http://www.revistas.usp.br/rdg/article/view/85433/88252.

Mariano, Z. De F. (2005) A importância da variável climática na produtividade da soja no Sudoeste de Goiás. [Doctoral dissertation Paulista State University]- Theses and Dissertations Archive. Instituto de Geociências Ciências Exatas, Universidade Estadual Paulista, Rio Claro - SP. $251 \mathrm{f}$. https://repositorio.unesp.br/handle/11449/104376

BRASIL. Conselho Nacional do Meio Ambiente. Resolução CONAMA № 001, 23 de Janeiro de 1986.

Massa, E. M; Ross, J. L. S. (2012) Aplicação de um modelo de fragilidade ambiental relevo-solo na Serra da Cantareira, bacia do Córrego do Bispo, São Paulo-SP. Revista do Departamento de Geografia - USP, Volume 24 (2012), p. 57-79. https://www.revistas.usp.br/rdg/article/download/52754/56609/66047

Morais, M. A. D.; CASTRO, W. A. C. D.; TUNDISI, J. G. (2010) Climatologia de frentes frias sobre a Região Metropolitana de São Paulo (RMSP), e sua influência na limnologia dosreservatórios de abastecimento de água. Revista Brasileira de Meteorologia, v. 25, n. 2, p. 205-217. https://doi.org/10.1590/S0102-77862010000200005.

Ross, J. L. S. Fierz, M. S. M. (2017) Geomorfologia Aplicada ao Planejamento Ambiental Territorial: Potencialidades e Fragilidades. P. 58-77. In: Redução do risco de desastres e a resiliência no meio rural e urbano.Org. Lourenço Magnoni Junior et al. São Paulo: Centro Paula Souza,214p.

Ross, J.L.S. (1994) Análise empírica da fragilidade dos ambientes naturais e antropizados. Revista do Departamento de Geografia - USP. São Paulo. n. 8, p. 63-73. https://doi.org/10.7154/RDG.1994.0008.0006

Ross, J.L.S. (2006) Ecogeografia do Brasil. São Paulo: Oficina de Textos. 208p.

Ross, J.L.S. Fierz, M.S.M. (2017) Geomorfologia Aplicada ao Planejamento Ambiental Territorial: Potencialidades e Fragilidades. In: Magnoni Junior, L (org.). Redução do risco de desastres e a resiliência no meio rural e urbano. São Paulo: Centro Paula Souza. São Paulo, Brazil, Cap. 5, p. 58-77. https://doi.org/10.11606/rdg.v37i0.151030

Santos, F.C. dos. (2008) Produtividade e aspectos nutricionais de plantas de soja cultivadas em solos de cerrado com diferentes texturas. Revista Brasileira de Ciência do Solo, v. 32, n. 5, set./out., p. 2015-2025, Editora: Fap UNIFESP. São Paulo-SP. https://www.redalyc.org/articulo.oa?id=180214065023

Santos, F.S.M. (2013) Avaliação de processos erosivos a partir da análise integrada do meio físico na Bacia Hidrográfica do Ribeirão das Pedras, Quirinópolis (GO). [Doctoral dissertation, Paulista State University Júlio de Mesquita Filho] Instituto de Geociências e Ciências Exatas do Campus de Rio Claro, Universidade Estadual Paulista Júlio de Mesquita Filho, theses and Dissertations Archive. $135 \mathrm{f}$. https://repositorio.unesp.br/handle/11449/102950

Santos, H. G. Dos; Jacomine, P. K. T.; Anjos, L. H. C. (2018) Sistema Brasileiro de Classificação de Solos. 5. Ed. Brasília, DF, Brazil. Embrapa. 356 p. https://www.infoteca.cnptia.embrapa.br/handle/doc/1094003

Souza, C.A.L.; Candeiro, C.R. (2012) Geologia e Paleontologia do Afloramento do Sítio I, Cretáceo Superior, Município de Prata, Minas Gerais, Brazil. Revista Sapiência: sociedade, saberes e práticas educacionais. IporáGO, v.1, n. 2, p. 2-22, jul/dez. http://www.revista.ueg.br/index.php/sapiencia/article/view/2685 